\title{
Assessing the Effects of Entrepreneurship Education in Private Universities in China
}

\author{
Yan Wang \\ School of Business \\ Wuhan Huaxia University of Technology \\ Wuhan, Hubei, China \\ mandy9905303@126.com
}

\author{
Lei Nie \\ School of Business \\ Wuhan Huaxia University of Technology \\ Wuhan, Hubei, China \\ nieleiem@foxmail.com
}

\begin{abstract}
Assessing the effects of entrepreneurship education in different national and cultural context or the type of universities is an important direction of the research field. Based on the commonly used model and scale in previous studies and adopting quasi-experiments with control group design this study conducted a questionnaire survey among the students in $\mathbf{1 5}$ private universities in Hubei province in China according to whether the respondents had received systematic school entre pre ne urship education. And the effects of entrepre neurship education in the universities were assessed by using t-test and ANOVA to compare the sample in the experimental group and control group. The results showed that the entrepreneurship education in the private universities positively impacted the students on their attitude towards entrepreneurship, perceived behavioral control and entrepreneurial intentions. This study is significant to understand the effects of entrepreneurship education in private universities in China and expands the insight of the related research field by the new context.
\end{abstract}

Keywords-entrepreneurship education; effect; assessing; private university; China

\section{INTRODUCTION}

Since the first entrepreneurship course was conducted at Harvard Business School in 1947, entrepreneurship education programs in higher education has gotten a great progress all over the world. This growth can be explained by two factors. First, the policy makers and educators in universities want to cultivate students' entrepreneurial knowledge, skills and right attitude towards entrepreneurship, or make more graduates to become entrepreneurs to start their own businesses and create jobs by offering entrepreneurship education programs in order to better fulfill their responsibilities to promote social and economic development. Second, the growing number of students having been interesting in entrepreneurship the relevant courses can meet their increasingly demands. It is usually considered that entrepreneurship education can foster more entrepreneurs having knowledge and ability to create economic value and jobs for the future. But in recent 10 years , increasing attentions have been paid to whether entrepreneurship education really played the expected role, because it is not only related to the allocation of funds and other resources such as time for the courses, but also how to improve the existing model of the education and promote the excellent practices through proper feedback ${ }^{[1][2][3]}$.

Supported by the Project of Educational Science Planning of Hube province in 2017" Current situation and effect evaluation of entrepreneurship education in private universities in Hubei province” (2017GB090).
Using quasi-experiments with control group design this study conducted a questionnaire survey among the students in 15 private universities in Hubei province in China according to whether the respondents have received systematic school entrepreneurship education. And the effects of entrepreneurship education in the universities were assessed through adopting t-test and ANOVA to compare the samples of two the groups. The results showed that the entrepreneurship education in the private universities positively impacted the students on their attitude towards entrepreneurship, perceived behavioral control and entrepreneurial intentions. This is significant to understand the effects of entrepreneurship education in the private universities in China and expands the insight of the related research field by the new context.

\section{LITERATURE REVIEW}

Entrepreneurship education can be broad defined as "holistic personal growth and transformation that provides students with knowledge, skills and attitudinal learning outcomes. This empowers students with a philosophy of entrepreneurial thinking, passion, and action-orientation that they can apply to their lives, their jobs, their communities, and their own new ventures" [4].

It is usually considered that entrepreneurship education can foster more entrepreneurs having knowledge and ability to create economic value and jobs for the future. But at present there are many theoretical and practical challenges on whether entrepreneurship education really has achieved the expected objects and how to evaluate the effects. And there is no consensus in the academic community [1][5][3]. The main challenges can be fitted into following three aspects. The first is the choice of generally accepted indicators of the assessment. The key questions of educational evaluation are to make clear the purpose of the assessment. But entrepreneurship education needs to meet different demands from its stakeholders ${ }^{[5]}$. Such as the politicians and policymakers interest in the perceived economic role of entrepreneurship education. Employers hope to hire a graduate who has more innovative ways of doing business and the discovery of new competitive products/services and new ways of marketing due to she/he has been educated in entrepreneurship courses. And Students may interest in favorable examination scores, satisfaction with course delivery, 
competence in the job market, and the realization of their career and financial aspirations. Therefore, most of the researchers are based on their own understanding of the purpose of entrepreneurship education to set evaluation indicators. And the characteristics of "fragmentation" in choosing the indicators of the assessment are very obvious ${ }^{[6]}$. The research of Mwasalwiba (2010) showed that in the literature about entrepreneurship education evaluation, the assessing indicators adopted by the researchers include seven main categories. The first is related to graduate start-ups. The second is associated with students' academic standards including examination scores and GPAs which is to evaluate students' knowledge and their potential for entrepreneurship. The third originates from psychological constructs, such as change in students' attitudes, perceptions, interest, selfefficacy, confidence, abilities and skills towards entrepreneurship. The fourth connects to contributions to the community for example technology transfer, new jobs created, or assistance to local entrepreneurs. The fifth is relevant to the student's interests and satisfaction with the course. The sixth is in terms of resulting innovations and graduates' business performance. And the last is used a change on students' needs of achievement and locus of control ${ }^{[6]}$. Secondly, the contextual factors in the university environment and the personal characteristics of the students can affect the outcomes of entrepreneurship education such as: (1) the level of school, internal culture, the situation of teachers , the initiatives, the available resources and the availability of funds to help finance venture creation projects; (2) the student's major and educational background, family environment, demographic characteristics, and involvement in entrepreneurship; (3) the goals, contents and teaching methods; (4) the institutional environment of the country which the university is located, etc. ${ }^{[1]}$. Thirdly, the time point of measurement can led the biases of the assessing results since some environmental factors that influence the effects of entrepreneurship education are changing with time such as "venture creation" may not possibly be measured immediately after an entrepreneurship education course ${ }^{[1]}$. The above analysis shows that a rigorous evaluation of entrepreneurship education should synthetically take account of various factors such as educational goals, environment and assessing time point.

Fayolle, et al (2006) considered that the effect evaluation of entrepreneurship education can't just stand in the academic position, but more attention should be paid to cultivating talents for the establishment of enterprises and solving the problems related to economic and policy decisions. In other words, the evaluation should be focused more on the social and economic impacts of entrepreneurship education. The entrepreneurship education has a direct and indirect impacts on the social and economic development that the direct impacts include the creation of new enterprises and the increase of jobs, and the indirect influences are mainly to improve individuals' entrepreneurship spirits. Therefore, students" "venture creation" and intentions for entrepreneurship should be as the most important indicators for the effect evaluation ${ }^{[1]}$. Existing studies also show that although researchers believe that the goals of entrepreneurship education are multiple, but a large numbers of them think that the two are the most important: one is to influence students' attitudes, behaviors, values and intentions for entrepreneurship; the two is to train students to become entrepreneurs [6]. Specifically, the former focuses on the cultivation of students' personal qualities, while the later emphasizes the venture creation by students. However, for the entrepreneurship education in universities, since there is the difference in time between the students' acceptance of entrepreneurship education and the establishment of their own enterprises it is difficult to exclude the impacts of the promotion or inhibition arising from the changes of environmental factors on the delayed measurement of "venture creation". Therefore, it is not appropriate to simply set up the "venture creation" by students as an indicator to evaluate the effects of entrepreneurship education[1]. Li \& Feng (2017) also believes that the goals of entrepreneurship education in China should focus on effectively improving students' awareness and ability of innovation and entrepreneurship[8]. The same views are also held in this study.

From the perspective that entrepreneurship education is mainly to cultivate students' attitudes, skills and other personal qualities towards entrepreneurship Fayolle, et al.(2006) proposed a general effect assessment model of entrepreneurship education program based on the theory of planned behavior (shown in Fig. 1)[1]. Because for entrepreneurs, entrepreneurial activity is an intentionally planned behavior that they plan to identify opportunities, establish and develop enterprises, the theory is suitable for explaining their behaviors. According to the theory of planned behavior, entrepreneurial intentions of individuals will be influenced by attitudes towards entrepreneurship, subjective norms and perceived behavioral control. There into the intentions refer to the efforts made by individuals for future performing entrepreneurship, including desirability and capabilities. The attitude refers to individual's judgement or evaluation of whether performing entrepreneurship is favorable. The subjective norms refer to individual's perceived social pressures to perform entrepreneurship from the various aspects of society such as family, friends and other important others. And the perceived behavioral control refers to individual's perception of the level of difficulty or controllability of performing entrepreneurship ${ }^{[1][9]}$. The application of the theory of planned behavior in the context of entrepreneurship education is to consider entrepreneurship education as a kind of investment in human capital. The human capital assets obtained by this investment are the students' attitude and the perceived behavior control toward entrepreneurship. And the outputs are the intentions and behaviors of the students to venture creation. Some environmental variables that influence the above factors can be embodied by "subjective norms". In other words, the effects of entrepreneurship education are mainly reflected in its influence on students' attitudes, subjective norms and perceived behavior control. Therefore, the factors related to entrepreneurship education such as the institutional setting, audience, type of entrepreneurship education programs, goals, contents and teaching methods etc. can be used as the prepositional variables of the attitude, subjective norms and perceived behavior control. When the model is to be used to assess the effects of entrepreneurship education one or more of the prepositional variables can be chosen according to the 
purpose of researchers And in the time dimension, this model can be used for longitudinal research, and the measurement of entrepreneurship education before, after, and during the middle period ${ }^{[1]}$. Because the theory of planned behavior is widely used in many fields to predict human behaviors, especially those that are rare, difficult to observe or where time lags exist ${ }^{[10][11]}$, the model suggested Fayolle, et al.(2006) is also widely cited in the evaluation of the effectiveness of entrepreneurship education ${ }^{[12]}$.

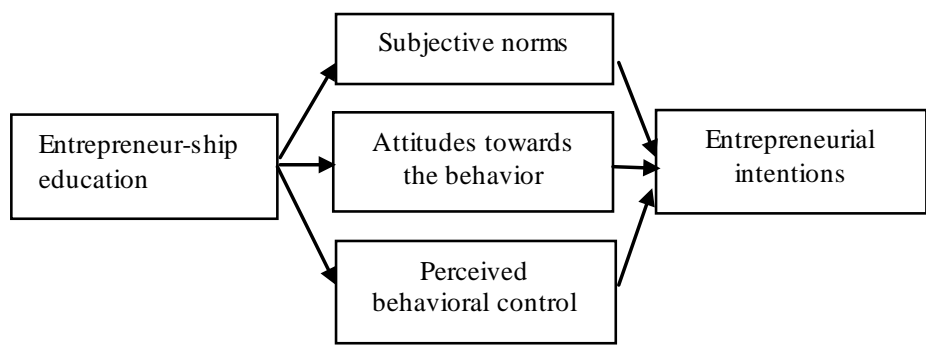

Fig. 1. The model of assessing the effects of entrepreneurship education

In the existing studies of the effects of entrepreneurship education quantitative methods are usually used. And the evaluation method also must be rigorous, because this will directly affect the accuracy of the results. The main characteristics of the rigorous criteria main include: (1) whether a causal relationship is between the measurement indicators and entrepreneurship education; (2) whether the evaluation indicators selected are under the guidance of relevant theories; (3) Whether the evaluation adopts ex ante/ex post or quasi-experiments with control group design ${ }^{\text {[2] [13] }}$.

According to the previous researches based on the theory of planned behavior, the positive effects of entrepreneurship education were mostly verified. But a small number of results showed that the effects were not obvious. Overall, the empirical evidences are not substantial ${ }^{[14][15]}$.

\section{Because of entrepreneurship education started later in}

China, how to evaluate the effects is still in the exploratory stage, and the relevant research, especially empirical studies using a rigorous method are relatively small. Some representative researches include XiangHui, \& Lei (2014); Du, \& Wang(2015); Tan, Cao, \& Song (2015); and Liu, \& Sun(2016).

Based on the above facts, this study assessed the effects of entrepreneurship education in Chinese private universities by using the model proposed by Fayolle, et al. (2006) ${ }^{[1]}$ and EIQ(entrepreneurial intention questionnaire) scale(Liñán, \& Chen, 2009) ${ }^{[9]}$, and adopting quasi-experiments with control group design.

\section{METHOD}

A online questionnaire survey was used to collect data. In June 2017, the investigators respectively sent the questionnaire to two groups of undergraduates from 15 private universities in Hubei province via internet. The one was experimental group that was composed mainly of senior students who confirmed to the investigators that they had completed the all courses of entrepreneurship education and had obtained credits. The another was control group which was composed mainly of lower grade students who not yet attended the entrepreneurship education courses or related training offered by schools or received related training. The study postulated that entrepreneurship education has played a positive effect if some or all of the values of attitudes towards entrepreneurship, perceived behavioral control, subjective norms and entrepreneurial intentions in the experimental group are significantly different and greater than the corresponding values in the control group.

\section{THE RESUlts}

The total of 242 questionnaires were sent out and collected in the survey. And the all of the questionnaires received are valid. The data obtained from the questionnaires were analyzed by the software SPSS22.0. And the results were as follow:

\section{A. The demographic characteristics of the respondents}

TABLE I. THE DEMOGRAPHIC CHARACTERISTICS OF THE RESPONDENTS

\begin{tabular}{|c|c|c|c|c|c|}
\hline \multirow{3}{*}{ Attributes } & Characteristics & \multicolumn{2}{|c|}{ The control group } & \multicolumn{2}{|c|}{ The experimental group } \\
\cline { 3 - 6 } & Population & $\begin{array}{c}\text { Frequency } \\
(\%)\end{array}$ & Populations & $\begin{array}{c}\text { Frequency } \\
(\%)\end{array}$ \\
\hline \multirow{3}{*}{ Gender } & Male & 65 & 53.3 & 68 & 56.7 \\
& Temale & 57 & 46.7 & 52 & 43.3 \\
& $17-19$ years old & 92 & 75.4 & 8 & 100 \\
\hline \multirow{4}{*}{ Age } & 20-21years old & 30 & 24.6 & 68 & 6.7 \\
& Over 21years old & 0 & 0 & 44 & 36.7 \\
& Total & 122 & 100 & 120 & 100 \\
\hline \multirow{3}{*}{ The majors of } & Art and sports & 7 & 5.7 & 12 & 10 \\
re-spoon- & Science \& engineering & 67 & 54.9 & 45 & 37.5 \\
dents & Business & 29 & 23.8 & 36 & 30 \\
& Social Sciences & 9 & 7.4 & 19 & 15.8 \\
& Others & 10 & 8.2 & 8 & 6.7 \\
& Total & 122 & 100 & 120 & 100 \\
\hline
\end{tabular}

Of the sample, $46.7 \%$ in the control group were female, now broadly in line with the general characteristics of students and $43.3 \%$ in the experimental group. And the students majoring in science \& engineering and business account for the majority of the two groups. The data are in universities. Therefore, it may be considered a representative sample. 


\section{B. The reliability and validity}

The questionnaire used in this study includes 20 Likert 5 point questions (0-Extremely disagree, 3-Neutral, 5-Extremely agree) that refers to the EIQ scale proposed by Liñán and Chen (2009) which has good reliability and validity. The EIQ scale also has been widely used in previous researches ${ }^{[15]}$. In the case, to further confirm the validity and reliability of the sample Cronbach's alpha was used to test its reliability and principal component analysis was conducted to verify the number of factors and to check the independence of the scale. The values of Cronbach's alpha for all items and each variable are listed in table 2 and 3 . And the values all greater than the 0.7 which is usual threshold level. The results of KaiserMeyer-Olkin test and Bartlett's sphericity test are showed in table2. These values indicate that the sample adequacy are notably high or significant. And it means that data are suitable for factor analysis. By principal component analysis three factors with eigenvalues greater than 1 emerged and the cumulative variance explained by the extraction was $61.245 \%$. Selecting varimax as the rotation method rotation converged after four iterations. The loading of the each item presented in the rotated factor matrix are listed in table 2. These data indicate that the validity of the sample can also meet the requirements.

TABLE II. THE RELIABILITY OF THE ALL QUEST IONNAIRE ITEMS AND THE FITNESS TEST OF FACTOR ANALYSIS

\begin{tabular}{|c|c|c|}
\hline Cronbach's $\alpha$ & KOM & Bartlett's test of sphericity \\
\hline 0.922 & 0.929 & $\begin{array}{c}\text { Approx. Chi-Square: } 2608.36(\mathrm{df}: \text { 190), } \\
\text { Sig.: } 0.000\end{array}$ \\
\hline
\end{tabular}

TABLE III. QUESTIONNAIRE ITEM, FACTORS LOADING AND RELIABILITY OF VARIABLES

\begin{tabular}{|c|c|c|}
\hline Items & Loading & Cronbach's $\alpha$ \\
\hline $\begin{array}{l}\text { Attitudes towards entrepreneurship(PA) } \\
\text { PA1: Being an entrepreneur implies more advantages than disadvantages to me } \\
\text { PA2: A career as entrepreneur is attractive for me } \\
\text { PA3: If I had the opportunity and resources, I'd like to start a firm } \\
\text { PA4: Being an entrepreneur would entail great satisfactions for me } \\
\text { PA5: Among various options, I would rather be an entrepreneur }\end{array}$ & $\begin{array}{l}0.593 \\
0.670 \\
0.742 \\
0.775 \\
0.693\end{array}$ & 0.820 \\
\hline $\begin{array}{l}\text { Subjective norms (SN) } \\
\text { SN1: If I decided to create a firm my parents and otherfamily members will support my decision } \\
\text { SN2: : If I decided to create a firm my friends will support my decision } \\
\text { SN3: If I decided to create a firm my classmates will support my decision }\end{array}$ & $\begin{array}{l}0.715 \\
0.747 \\
0.823\end{array}$ & 0.755 \\
\hline $\begin{array}{l}\text { Perceived behavioral control(BC) } \\
\text { BC1: To start a firm and keep it working would be easy for me } \\
\text { BC2: I am prepared to start a viable firm } \\
\text { BC3: I can control the creation process of a new firm } \\
\text { BC4: I know the necessary practical details to start a firm } \\
\text { BC5: I know how to develop an entrepreneurial project } \\
\text { BC6: If I tried to start a firm, I would have a high probability of succeeding }\end{array}$ & $\begin{array}{l}0.734 \\
0.591 \\
0.683 \\
0.730 \\
0.797 \\
0.743\end{array}$ & 0.859 \\
\hline $\begin{array}{l}\text { Entrepreneurial intentions(PI) } \\
\text { PI1: I am ready to do anything to be an entrepreneur } \\
\text { PI2: My professional goal is to become an entrepreneur } \\
\text { PI3: I will make every effort to start and run my own firm } \\
\text { PI4: I am determined to create a firm in the future } \\
\text { PI5: I have very seriously thought of starting a firm } \\
\text { PI6: I have the firm intention to start a firm some day }\end{array}$ & $\begin{array}{l}0.793 \\
0.715 \\
0.626 \\
0.785 \\
0.754 \\
0.675\end{array}$ & 0.903 \\
\hline
\end{tabular}

\section{Analysis of the difference between the experimental group} and the control group

entrepreneurship(PA), perceived behavior control(BC), subjective norms(SN), and entrepreneurial intentions(PI)

To evaluate the effects of entrepreneurship education the difference of the sample of attitude towards between the experimental group and control group was analyzed by t-test and ANOVA. The results are showed in the table 4,5 , and 6 .

TABLE IV. DESCRIPTIVE ST ATISTICS

\begin{tabular}{|c|c|c|c|c|c|c|}
\hline \multirow{2}{*}{ Variable } & \multirow{2}{*}{$\mathrm{N}$} & \multirow{2}{*}{ Mean } & \multirow{2}{*}{ Std. Deviation } & \multirow{2}{*}{$\begin{array}{l}\text { The difference between the mean of the two } \\
\text { groups }\end{array}$} & \multicolumn{2}{|c|}{ 95\% Confidence Interval of the Mean } \\
\hline & & & & & Lower & Upper \\
\hline PA & 120 & 3.3400 & 0.7798 & 0.2810 & 3.1990 & 3.4810 \\
\hline $\mathrm{PH}$ & 122 & 3.0590 & 0.8331 & 0.2010 & 2.9097 & 3.2083 \\
\hline SN & $\begin{array}{l}120 \\
122\end{array}$ & $\begin{array}{l}3.3056 \\
3.1913\end{array}$ & $\begin{array}{l}0.8103 \\
0.7901\end{array}$ & 0.1143 & $\begin{array}{l}3.1591 \\
3.0496\end{array}$ & $\begin{array}{l}3.4520 \\
3.3329\end{array}$ \\
\hline$B C$ & 120 & 2.7569 & 0.7317 & 02341 & 2.6247 & 2.8892 \\
\hline $\mathrm{DC}$ & 122 & 2.5328 & 0.7953 & $0.2 \angle 41$ & 2.3902 & 2.6753 \\
\hline PI & $\begin{array}{l}120 \\
122 \\
\end{array}$ & $\begin{array}{l}2.8972 \\
2.4577\end{array}$ & $\begin{array}{l}0.8065 \\
0.8789 \\
\end{array}$ & 0.4395 & $\begin{array}{l}2.7514 \\
2.3001 \\
\end{array}$ & $\begin{array}{l}3.0430 \\
2.6152\end{array}$ \\
\hline
\end{tabular}

TABLE V. INDEPENDENT SAMPLE T-TEST

\begin{tabular}{|c|c|c|c|}
\hline Variable & Sig. (Equal variances assumed) & T Value & Sig. (2-tailed) (Equality of Mean) \\
\hline PA & 0.938 & 2.708 & 0.007 \\
\hline SN & 0.330 & 1.111 & 0.268 \\
\hline BC & 0.153 & 2.281 & 0.023 \\
\hline PI & 0.071 & 4.052 & 0.000 \\
\hline
\end{tabular}


TABLE VI. ANOVA

\begin{tabular}{|c|c|c|c|c|}
\hline & PA & SN & BC & PI \\
\hline F & 7.332 & 1.234 & 5.202 & 16.418 \\
\hline Sig. & 0.007 & 0.268 & 0.023 & 0.000 \\
\hline
\end{tabular}

According to the data in the table4, 5, and 6, it can be found: (1) There are significant differences between the experimental group and the control group in terms of the three variables of PA, BC and PI, and the mean of the three variables in the experimental group were greater than those in the control group. This shows that entrepreneurship education has a positive impact on students' attitude toward entrepreneurship, perceived behavior control and entrepreneurial intentions. (2)There is no significant difference between the experimental group and the control group in the mean of variable SN. This indicates that entrepreneurship education has no obvious impacts on the subjective norms of students. This result is the same as some of the previous researches (Lortie, \& Castogiovanni, 2015). (3) The 95\% confidence intervals of the three variables on PA, BC and PI are [3.1990,3.4810], [2.6247,2.8892] and [2.7514,3.0430] respectively. This shows that although students had completed the all courses of entrepreneurship education and obtained credits the mean of their attitude toward entrepreneurship, perceived behavior control and entrepreneurial intentions was close to the neutral level. That is to say, the entrepreneurship education in private universities still needs to be improved, especially in how to enhance their students' perceived behavior control or self-efficacy toward entrepreneurship.

\section{CONClUSIONS AND Discussions}

Previous studies have shown that the cultural and institutional environments of a country and the types of universities are important factors that affect the effectiveness of entrepreneurship education ${ }^{[3]}$. Therefore assessing the effects of entrepreneurship education in the different context is an important direction of the research field. Based on the background of private universities in China, this study adopted a quasi-experiments with control group design and assessed the effect of their entrepreneurship education. Through the analysis of the differences on the attitude towards entrepreneurship, perceived behavior control, and entrepreneurial intentions between the two groups of samples it can be seen that except "subjective norms" there were significant differences between the experimental group and the control group in the mean of the other three variables, and the mean of the three variables in the experimental group were also greater than those in the control group. This shows that the entrepreneurship education has a positive impacts on students' attitude towards entrepreneurship, perceived behavior control and entrepreneurial intentions, that is to say, the entrepreneurship education in private universities has played an expected effects. In this study the model of effect evaluation and the measurement scale are commonly used in previous studies, and the assessing method also conforms to the rigorous standards. Therefore, the accuracy of the results is high. This is significant to understand the effects of entrepreneurship education in the private universities in China and expands the insight of the related research field by the new context.
The samples selected in this study included the students with interdisciplinary background, in order to reduce the impacts of the individual characteristics of the respondents on the effect evaluation. But the respondents came from the same province. And although the respondents were all from private universities, the possibility of the impacts of the heterogeneity of institutions, the courses contents and teaching methods of entrepreneurship education on the evaluation could not be completely eliminated. These are the main limitation of the study.

\section{REFERENCES}

[1] Fayolle A., Gailly B., "Lassas-Clerc N. Assessing the impact of entrepreneurship education programmes: a new methodology”, Journal of European Industrial Training, 2006, 30(9), pp.701-720.

[2] Lorz M, Mueller S, Volery T, et al, "Entrepreneurship education: A systematic review of the method in impact studies", Journal of Enterprising Culture, 2013, 21(02), pp.123-151.

[3] Nabi G, Linan F, Krueger N, et al, "The impact of entrepreneurship education in higher education: A systematic review and research agenda”, Academy of Management Learning \& Education, 2017, 16(2),pp.277299.

[4] Gedeon S A, "Application of best practices in university entrepreneurship Education”, European Journal of Training and Development, 2014, 38(3), pp.231-253(23).

[5] Duval-Couetil N, "Assessing the impact of entrepreneurship education programs: Challenges and approaches”, Journal of Small Business Management, 2013, 51(3), pp.394-409.

[6] Mwasalwiba E S, “Entrepreneurship education: a review of its objectives, teaching methods, and impact indicators", Education + Training, 2010, 40(1), pp.72-94.

[7] Walter S G, Block J H, “Outcomes of entrepreneurship education: An institutional Perspective”, Journal of Business Venturing, 2015, 31(2), pp.216-233.

[8] Li Y.,Y., Li J., \& Feng X, “The origin, evolution and prospect of entrepreneurship education in China” , Journal, 11(3), pp.6-14. (In Chinese)

[9] Liñán F, Chen Y W, "Development and cross-cultural application of a specific instrument to measure entrepreneurial intentions", Entrepreneurship Theory and Practice, 2009, 33(3),pp.593-617.

[10] Krueger N, Reilly M D, Carsrud A, "Competing models of entrepreneurial Intentions”, Journal of Business Venturing, 2000, 15(5),pp.411-432

[11] Lortie J, Castogiovanni G, "The theory of planned behavior in entrepreneurship research: what we know and future directions", International Entrepreneurship \& Management Journal, 2015, 11(4),pp.123.

[12] Liñán F, Fayolle A, “A systematic literature review on entrepreneurial intentions: Citation, thematic analyses, and research agenda”, International Entrepreneurship \& Management Journal, 2015, 11(4), pp.907-933.

[13] Rideout E C, Gray D O, “Does entrepreneurship education really work? A review and methodological critique of the empirical literature on the effects of university-based entrepreneurship education”, Journal of Small Business Management, 2013, 51(3), pp.329-351.

[14] Fretschner M. Ajzen, “Theory of planned behavior in entrepreneurship education research”, Becoming an Entrepreneur. Rotterdam: Sense Publishers, 2014, pp.249-277.

[15] Liñán F, Fayolle A, “A systematic literature review on entrepreneurial intentions: Citation, thematic analyses, and research agenda”, International Entrepreneurship \& Management Journal, 2015, 11(4), pp.907-930. 